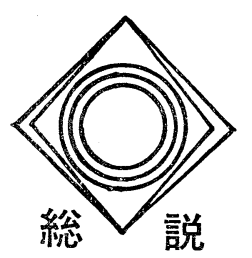

\title{
炭化反応における光学的異方性組織の 展開のための基本設計
}

\author{
-1979. 3.8 受理一
}

\author{
九州大学* 持田勲, 安藤蕯* \\ 竹下 健次郎
}

\section{1. 序}

エネルギー危機以来, 重質炭素資源の高度利用の観 点から重質油の利用技術開発が広く追求されている。 重質油は分解軽質化, 縮合ピッチ化, 炭化によって付 加価値をあげることができる。多くの場合，これらの プロセスは併発するので, 生成物のすべての付加価值 を高めることが望まれている。炭化反応において生成 するコークの品位の尺度のひとつに光学的異方性組織 がある。光学的組成展開は異方性単位の寸法打よび形 状によって記述できるが1)，この展開程度によって， コークは炭素材としての種々の利用が可能となる。光 学的に流れ組織を有するコークスは，結晶子の高い配 合性と易黒鉛化性のニードルニークスとして有用であ $り^{22}$ ，モザイク組織，等方性組織のコーク多機械的強 度の大きな等方性材料としての用途がある ${ }^{3)}$ 。一方， 光学的異方性組織が展開し終わる以前のメソフェーズ の状態からはピッチ系高弾性炭素瀻維を製造すること 己可能で), 同プロセスは世界各地で研究されてい る。このように, 炭化反応の評価に際しては, 光学的 異方性組織が重要なバロメーターになっており，この 組織の展開を自由に制御できれば，重質油利用に新た な道が拓けると期待できる。光学的異方性組織展開の 制御は，ひと口で言えば熱分解過程に扮ける反応相の 制御ということになり，これは重質油利用の他のプロ セスと密接に関連している。したがってここで得られ た知識は同時に他のプロセスの制御に関する基礎とな りうる。本説では, 異方性組織展開機構の理解に基う く，同組織展開制御の方法論のひとつを紹介したいと 考えている。

\section{2. 炭化反応機構}

2.1 光学的䔬方性の出現する炭化反応の経路 ある種の有機試薬，アスファルト，ピッチ，石炭な ぞの有機化合物がある温度で軟化溶融し，さらに縮合

* 生産科学研究所 福岡市東区箱崎 6-10-1

* 現在 出光興産
し，メソフェーズと呼ばれる一種のネマチック液晶を 経て固化し，光学的異方性組織空有する炭素体を生成 することは, Brooks, Taylor ${ }^{5)}$ 以来, 数多くの研究者 によって認められている。この異方性組織は黒鉛化 性, 熱膨脹係数などの炭素体の物性と密接に関連する 構造因子であることもよく知られている6)。芳香族化 合物であるナフタレン（잉ㅇ）を塩化アルミニウム 存在下（触媒0.1モル比）で炭化するとメソフェーズを 経て, ニードルコークスに共通する光学的異方性流れ 組織を展開する。一方，同じ芳香族化合物であるピレ ン ( 100 ) 年同様の条件で炭化すると異方性化する が，その組織はモザイク状である7。多環芳香族は脱 水素, 環化, 重縮合の諸過程をたどって高分子化し, その結果, 凝集固化して炭素前駆体に至る。この一連 の化学的, 物理的過程で形成される炭素前駆体の組織 構造は，原料種のみならず，炭化条件により強く影響 される8!。したがって，類似化合物であるナフタレン とピレンとが性状の異なる炭素体を生成する要因も, こうした化学的, 物理的過程の差異に根ざしていると 考兄られる。またこのことは, 同一原料であってる炭 化条件の変更により炭素の組織を制御できることも意 味する。ここに炭化反応設計の基䝪が岕るが，設計を 可能にするためには炭化反応の機構を決定する因子索 把握して，その制御法を考案することが必要となる。

多環芳香族分子が凝集し，秩序ある集合体（メソフ ェーズ）を形成するためには，巨大分子が炭化相を自 由に運動し，配列することが必要である。高分子量炭 素前駆体の凝集配列は， $\pi$ 電子間の相互作用を駆動力 (driving force) とするため, 円滑な移動が必須で, それには炭化系の, 特に固化直前での粘度が十分に低 くなければならない。一方, 高分子化に伴い, 孷化系 の粘度は次第に增加するから，二つの過程が調和する

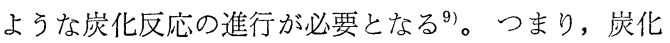




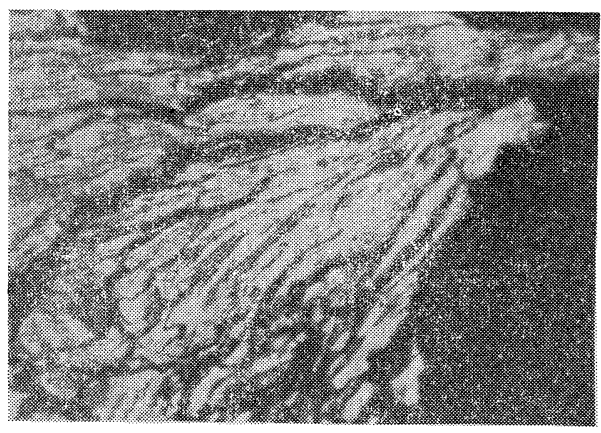

a)

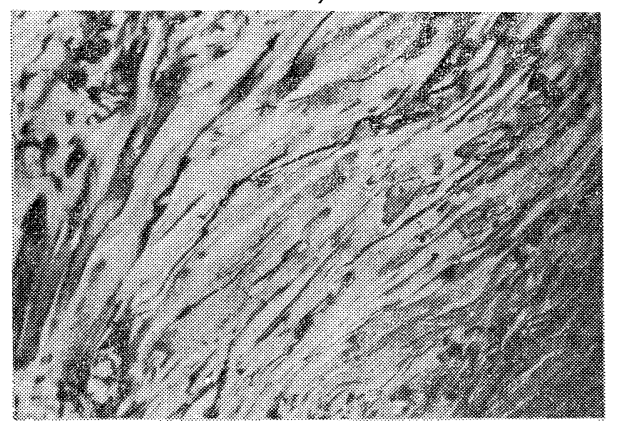

c)

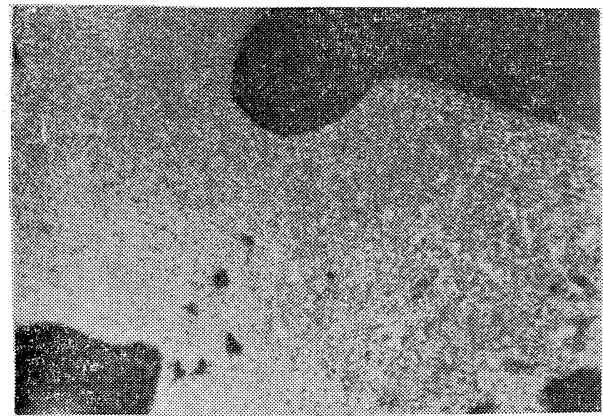

e)

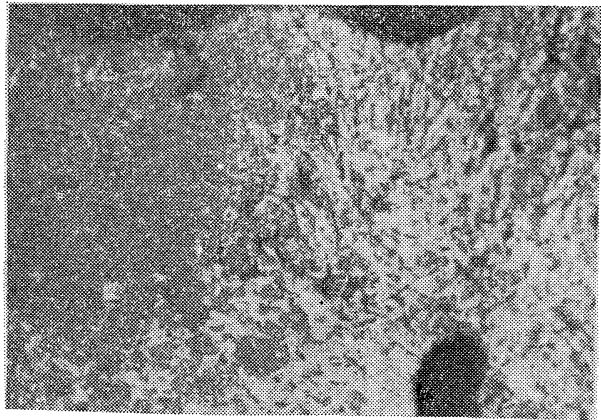

b)

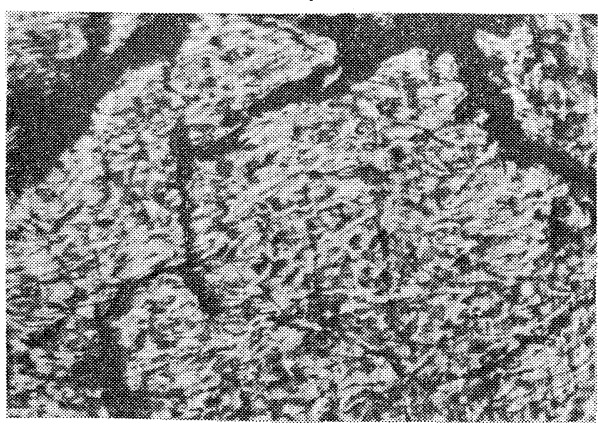

d)
a) カルバゾール
b) アクリジン c) ジフェ
ニレンスルフィド
d) テオキサンテン
e) チ
アンスレン

図 1. 異節環化合湖の触媒炭化により生成する炭素の偏光顕微鏡写真 $\mathrm{AlCl}_{3}$ : 0.5 モル比, 炭化温度 $600^{\circ} \mathrm{C}-2$ 時間

過程に打ける高分子化と反応相の低粘性という相反す る 2 つ要因学同時に満足する炭化系を設定して，異 方性組織の展開が可能となる。

2.2 炭化時の溶融性と中間体の構造

低分子量モデル化合物の炭化挙動を調べることは， 炭化反応に関与する分子種の同定も部分的には可能で あるから，その炭化機構の解明はピッチなどの複雑な 混合物などに比皎して幾分容易であろう。筆者らは， ナフタレンおよびピレンの触媒（アルカリ金属熍るい は塩化アルミニウム）炭化に打ける炭化中間体の棈造 とベンゼン不溶分の生成を目安とする炭化反応速度を
調べ，これらの因子の生成㟶素の光学組織に与える影 響を解析した ${ }^{10)}$ 。

ヘテロ原子（N, S ）を含む芳香族化合物について も塩化アルミニウム存在下で炭化し, 炭化中間体の構 造や炭化速度から炭化機構が検討できる11)12)。図 1 は 窒素原子を含むカルバゾール，アクリジン，硫黄原子 を含むジフェニレンスルフィド, チオキサンテン, チア ンスレンの各化合物を壏化アルミニウム存在下 $600^{\circ} \mathrm{C}$ で炭化し，生成する炭素体の偏光顕微鏡写真である。 カルバゾール，ジフェニレンスルフィドが流れ，チオ キサンテンがモザイク組織，アクリジン，チアンスレ 


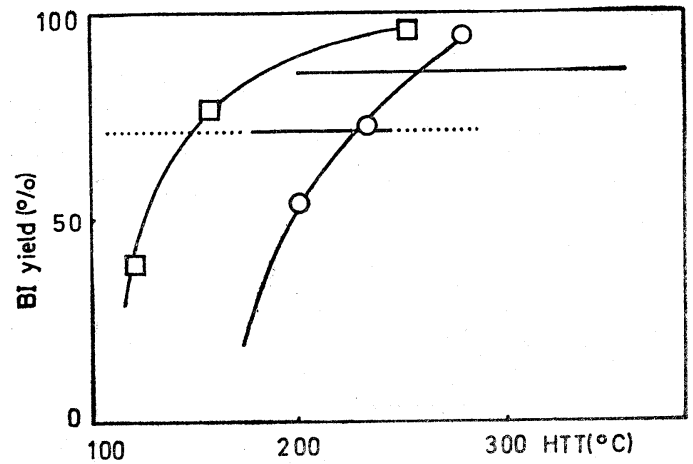

○カルバゾール ロロアクリゾン

一低粘性溶融域 ……高粘性溶融域

因 2 罢素化合物の触蝶炭化における BI 分の生 战速膺 $\mathrm{AlCl}_{3}: 0.5$ モル比

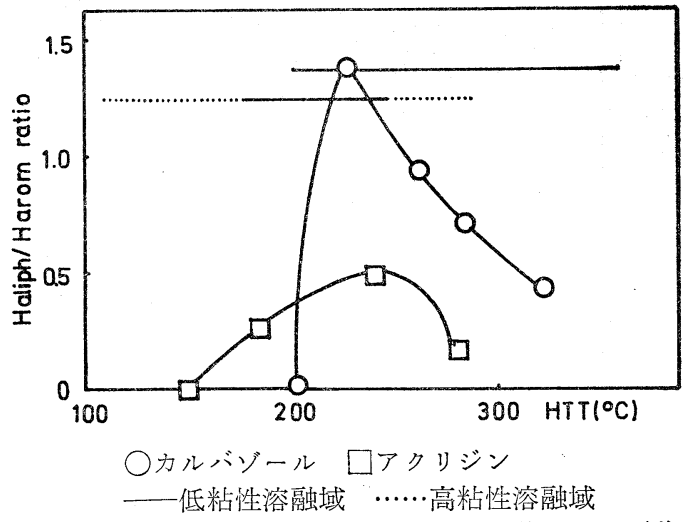

図 3 硫黄化合物の触媒炭化中間体の脂肪族水菜/芳 香族水索比と溶融域 $\mathrm{AlCl}_{3}: 0.5$ モル比

ンが一部等方性を含む微細モザイク組織の炭素を生成 する。図 2 はカルバゾール(a)とアクリジン(b)の溶融域 とベンゼン不溶分 (BI) の増加を示したものである。 両化合物の炭化溶融域幅は大きく異なる。これは, カ ルバゾールでは BI が90\%に達しても溶融状態を維持 しているのに対して，アクリジンでは BI が70\%に達 すると粘度が上昇し，プラスチック状態となり，90\% に達する時には，系は固化していることと対応する。 さらにこの差異は, 中間体, 特に炭化反応中にマトリ ックスを形成している分子種の構造の差によるものと 考えられる。BI-AS (アセトン可溶分) の NMR スペ クトルを図 3 に示すが，カルバゾールから生成する中 間体はアクリジンからのそれに較べて能肪族水素が多 量, かつ広い温度域で存在しており, カルバゾールの 溶融域が広いことと対応している。つまり，中間体の 構造の差に基づく溶融域幅が生成炭素の光学組織と結 びついているといえよう。ジフェニレンスルフィド,
チオキサンテン，チアンスレンなどの硫黄化合物も同 様の方法で調べることができる。炭化速度と溶融域と をこれらの化合物について，此較して図 4 に示す。ジ フェニレンスルフィドの炭化速度は他の 2 化合物に比 較してゆるやかである。チアンスレンはふなり低温で 固化が進行し，その溶融域が極めて枿い。溶融性を左 右する炭化中間体中の BS 分の構造を比較すると, シ フェニレンスルフィド，チオキサンテンが固化㨁前ま でかなりの脂肪族水素が存在するのに対し，チアンス レンにはほとんど見られない(眓5)，以上のような脂肪 族水素は，芳香環が縮合する際に生成するナフテン環 水素と推定され ${ }^{13)}$, 溶融に重要な役割を果している。

Edstrom, Lewis ${ }^{14)}$, るいは大谷ら ${ }^{15)}$ は, 炭化出発 分子の化学構造と生成する炭素の黒鉛性との関連につ

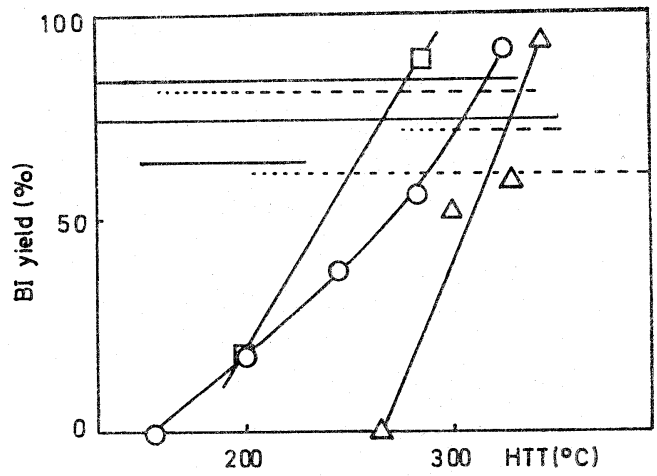
○ジフェニレンスルフィド $\triangle$ メオキ+ンテン ロチアンスレン

\section{— 溶融域 $\quad \cdots . .$. 脱硫域}

図 4 硫黄化合物の触媒炭化にむける $\mathrm{BI}$ 分生践速度 と溶融域

$\mathrm{AlCl}_{3}: 0.5$ モル比

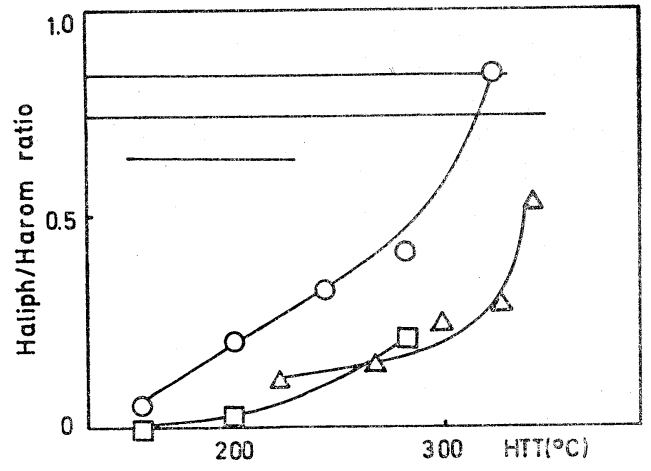

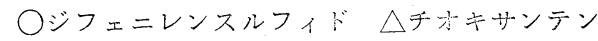
ロチアンスレン

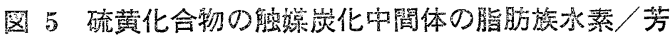
香族水素比と溶融域 $\mathrm{AlCl}: 0.5$ モル比 
いて，分子の平面性，出るいは立体的混み合い， $\mathrm{SP}^{3}$ 炭素一重結合の観点から調べている。これは, メソフ ェーズにおける構成分子の積層秩序化が可能なために は，分子が平面でないとむずかしいという理解に基ら゙ いている。メソフェーズに扔いて構成分子の非平面性 がどの程度許容されているかは未だ明確でないが，

(メソフニーズ構成分子の構造については筆者ら ${ }^{16}$ ) 拉 よび White ${ }^{17)}$ の論文がある) 著しく強固な非平面性 分子がメソフェーズに組みこまれにくいことは容易に 想像できる。しかし同時に，炭化反応中においては出 発分子は種々の化学反応を経験するわけで，その間に 非平面性を解消するような反応が起これば，このメソ フェース゚形成の困難点は自然と解決されることになる ので, 出発分子の構造は炭化反応中間体の構造を決定 する上で影響を持つとはいえ，絶対的要因とは必ずし も考党る必要はない。すなわち, 炭化反応は動的に考 察しなければならない。

\section{3 岸化中のへテロ原子の挙動}

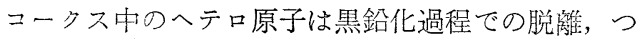
まりパッフィング現象により炭素材の品位を低下せし める。さらに, 高䟽黄含有ピッチからはニードルュー クスが生成しないことから，炭化原料のへテロ原子が 炭化性に影響すると考兄られている18)。炭化中のへテ 口原子の挙動はこうした二つの観点から炭化反応の機 構上重要な因子となっている。大谷ら ${ }^{19}$ は，窒素を含 む環状化合物であるテトラベンゾフェナジンが窒素原 子を浮とんど脱離することなく、メリフェーズを経由

して，置方性炭素定生成すると報告している。

先に的述べた通り, 窒素, 硫黄を含む芳香族化合物 カルバゾール，アクリシン， ジフェニレンスルファイ ド，チオキサンチン，チアンスレンは塩化アルミニウ ム存在下で高收率で炭化し, 図 1 に示すように, 種及 の光学絽織学もつ炭素を生成する ${ }^{1112)}$ 。異節環内の硫

表 1 ヘテロ原子の総噰

\begin{tabular}{|c|c|}
\hline ジフェニレンスルフィド & $45^{*}$ \\
\hline チオキサンテン & 54 \\
\hline チアンスレン & 32 \\
\hline カルバゾール & $74^{* *}$ \\
\hline アクリジン & 89 \\
\hline フェナジン & 76 \\
\hline
\end{tabular}

*脱硫率 $=\frac{\text { 炭化中に発生する硫黄量 }(\mathrm{g})}{\text { 原料化合物中の硫黄量 }(\mathrm{g})} \times 100$

**窒素残存率 $=$ 生成炭素中の窒素含有率 $(\%)$ 原料化合物中の窒素含有率 $(\%)$
黄原子は炭化中に炭化する化合物の榡造や条件にっ よて, ある程度脱離する。窒素は $600^{\circ} \mathrm{C}$ で炭化しても ほとんど脱離せず, 大谷らの結果 ${ }^{19)}$ とく一致してい る。さらに表 1 に示すように, 生成炭菜中の窒素残留 率，あるいは脱硫率と生成炭素の配向性の間には直接 の関係は認められない。ただ，チアンスレンからの脱 硫率が $30 \%$ 程度と著しく低いことが，炭化中間体の反 応性や構造を通して, 微小モザイク炭素の生成と何ら かの関係があるかもしれない。

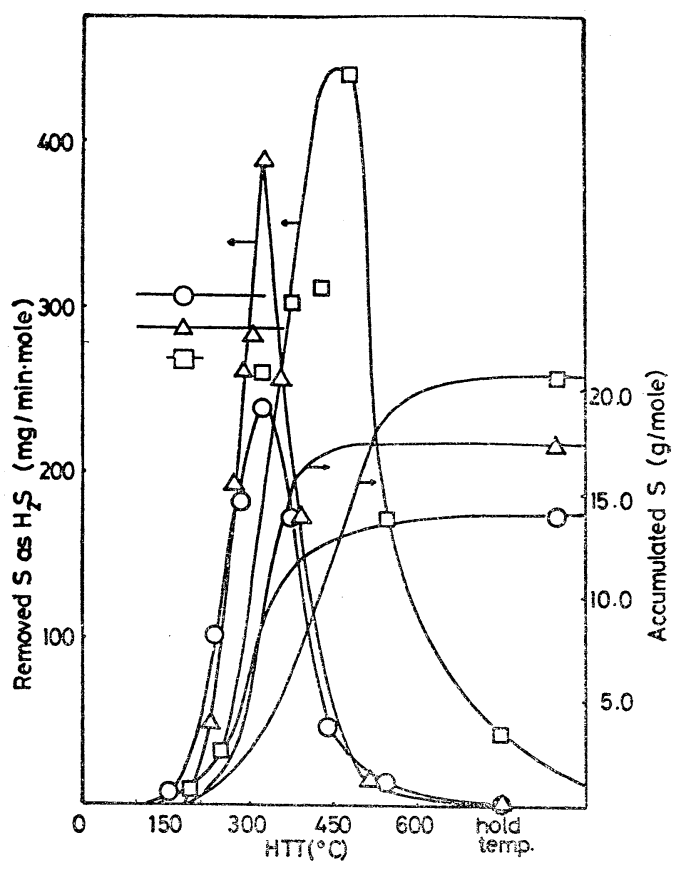

○ジフェニレンスルフィド $\triangle$ チオキサンテン ロチアンスレン

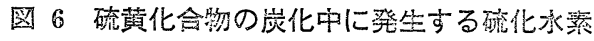
$\mathrm{AlCl}_{3}: 0.5$ モル比

一方, 脱硫速度と炭化の進行といった動的観 点か ら, これらの硫黄化合物の炭化性を比較すると, 図6 に示すようにかなり異なった様相を示す。チアンスレ ンは固化後に脱硫が起こる点が他の二つの化合物と異 なる。チアンスレンが一部等方性の微小モザイク炭素 を与えることを考光ると，溶融域における硫黄の存在 が硫黄, 硫黄結合の形成によって溶融状態を狭ばめる ことを通して，メソフェーズ形成に何らかの影響を与 えていることは岁りえる。カフジ減圧残查油（5\%程 度硫黄を含有）を水紊化脱硫後，炭化して得られるコ 一クスの光学的組織は硫黄含有率の大きな減少にもか かわらず，モザイクで㟧った。一方，適当量の塩化ア ルミニウムを共存させると，硫黄含有率の $30 \%$ 程度の 
減少にかかわらず，同残查油からも良好な流れ組織が 生成する。このように, 硫黄, 窒素原子の異節環内に 打ける存在は必ずし为生成コークスの光学組織に深刻 な影響を与えるとはい光ない。元素硫黄の添加が異方 性展開を阻害することは知られている19)。架橋構造が 溶融性を消失せしめることは高分子化合物においてし ばしば認められる事実である。

窒素や硫黄とちがって, 酸素を含有する芳香族化合 物は等方性が高久微小モザイク組織のコークスを与兄 るのみで, 酸素原子がメソフェーズ形成成長を阻害す る要因を有していると思われる。酸化による異方性展 開20)の阻害も報告されている。

ここでは常圧下での炭化反応について述べたが，压 カ下の炭化ではカルバゾールなどの含窒素化合物から 高強度材料となる等方性コークが生成すると報告され ている ${ }^{21 \%}$ 。

含硫黄化合物は，酸触媒の存在下では $200 \sim 400^{\circ} \mathrm{C}$ の 温度域で硫化水素を発生するので, 脱硫反応が進行し ていることは明白である。高価な水素を使用しない脱 硫技術の開発は，重質油を炭素材原料としての利用を 考光る際には特に望まれるものである。図 6 に示した

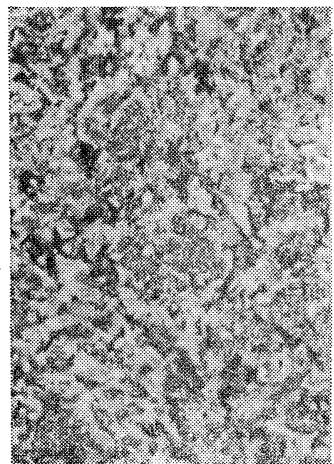

d)

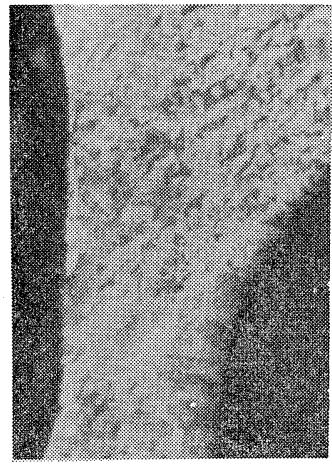

b)
ように，含硫黄化合物からの硫化水素の発生はその化 学構造に依存し，チアンスレンのように実質的に脱硫 が固化後に開始する場合もあり, そのため, 脱硫率が 低い值にとどまるのであろう。

\section{3. 炭化反応制御法としての共炭化}

炭化性に影響を与える因子を制御すれば，生成炭紊 の構造改善が可能であることは, 理論的にも実験的に も明らかである。出発有機化合物の岸化性が構造修飾 により改質されることも22)そのひとつの例である。種 หの炭化性因子について, 沶の新の, 制御法があり るが炭化機棈で述べたと㧍り, 固化直前に至る過程で, 低粘度溶融状態を維持することが光学的異方性展開の 本質的に重要な条件であると考光れば，第 2 成分の添 加により，この条件が满たさるようにすることが可能 であろう。例觉ば，単独で炭化すれば等方性あるいは モザイク構造の炭素を与える試料に，他の試料をわず かに渿加することにより，その炭化物を高度の流れ組 織に改質することができるということも夢ではない。 本説では，共炭化により原理的にはいかなる原料から もニードルコークス (流れ組織) の製造が可能である ことを示唆し，その炭化機構を考察する。

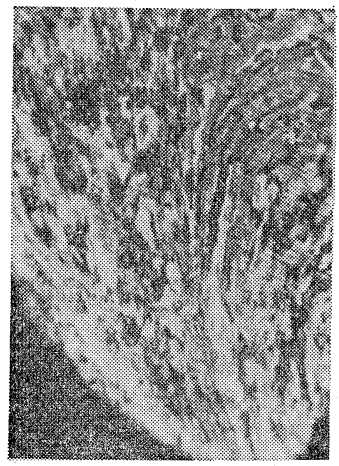

c)

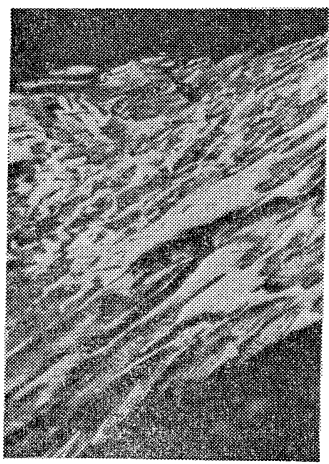

d)
a) $0 / 10 \quad$ b) $2 / 8$
c) $3 / 7$
d) $10 / 0$

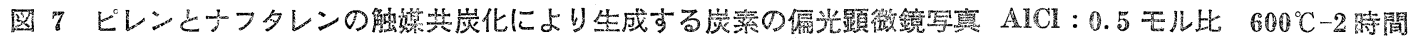
ナフタレン/ピレン比

図 7 はピレンとナフタレンの共炭化により生成する 炭素の偏光蹎微鏡写真条㟧る23)。ピレンは塩化アルミ ニウムを 0.1 モル比加えて単独で炭化すると，モザイ ク構造の炭菜堂生成し, ナフタレンは流れ構造の炭素 を生成する。両者を混合して, 塩化アルミニウム存在 下で共崖化すると, 配合比により光学組織の異なる炭 素を与亮, ナフタレンの量がモル比なではモザイク状 炭素が生成するが，0.3 モル比以上加劣ると流机構造 の炭素に変化する。つ交量的にはナフタレンの方
が少量であるにもかかわらず，炭化生成物あるいは炭 化反応はナフタレンに支配されていることになる。 Marsh らはこのような效果を“Dominant Partner Effect”と名付けた ${ }^{24)}$ 。

図 8 は異節環化合物をアントラセン，交たは9,10一 ジヒドロアントラセンと共炭化した結果である25)。前 節で述べたように, 窒素を含さアクリジン, 硫黄を含 むテアンスレン, 酸素を含むキサンテンは単独で炭化 すると, 微小モザイクまた等方性の炭素を与える化 
a)

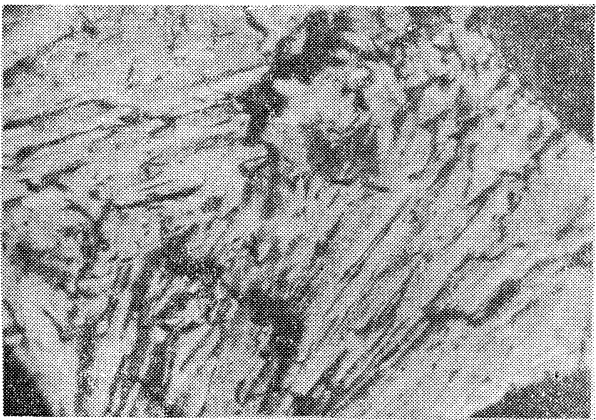

b)

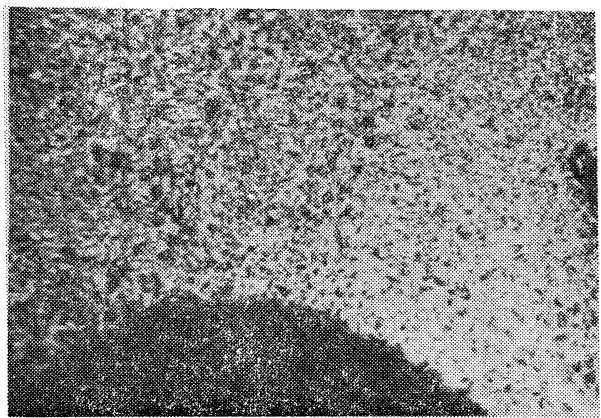

d)

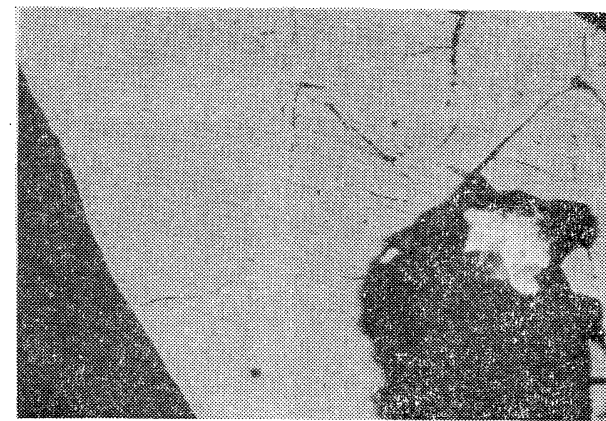

c)

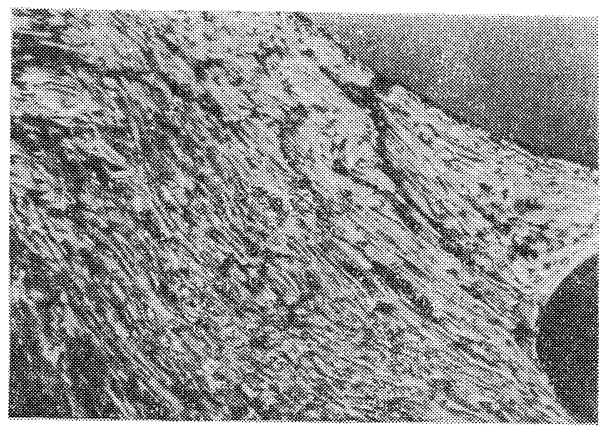

e)

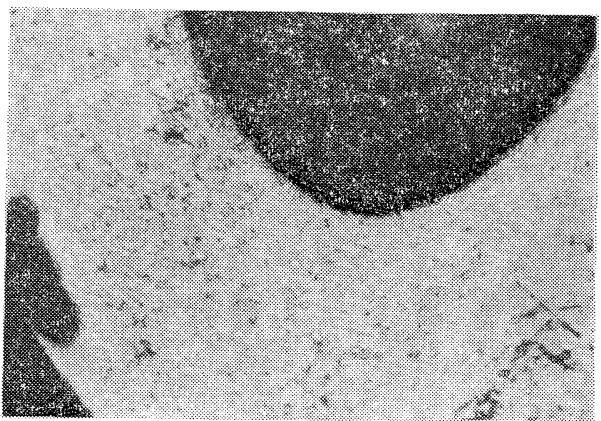

a) アクリジン/アントラセン $=1 / 0.3$

b) チアンスレン/アントラセン $=1 / 1$

c) チアンスレン/ジヒドロアントラセン $=1 / 1$

d） キサンテン /アントラセン $=1 / 1$

e) キサンテン/アントラセン $=1 / 1$

图 8 篊節環化合物とアントラセンまたは 9,10 -ジヒドロアントラセンの触嫫共炭化により生成する 宸素の偏光顕徽鏡穷嘪

合物であるが，アントラセンと共炭化すると異方性組 織が出現するようになる。

図 8 a はアクリジンとアントラセンを1.0/0.3 モル 比で混合し，塩化アルミニウム存在下で炭化した炭素 の偏光顕微鏡写真で方るが，流れ構造を与えている。 これはピレンとナフタレンの場合に類似して录り, ア クリジンの炭化性も, その $1 / 3$ の量しかないアントラセ ンの炭化性に支配され, 流れ組織を展開したものと思 われる。チアンスレンにアントラセンを不モル比混合 して, 同様に炭化すると, アクリジンほど効果は大き
くないが，全面が異方性モザイク組織の炭素に変化し さらに9,10-ジヒドロアントラセンと混合すれば流れ 造の構炭素が生成する。アントラセンに較べて, 水素 化物である9,10-ジヒドロアントラセンの方が異方性 組織展開に効してより効果が大きい。キサンテンとア ントラセンの共孷化 (1 1 亿 ル比) では, 異方㤬の出現 は認められるが，微小モザイク程度である。をた，ア ントラセンの量をキサンテンの 5 倍量に增やしても, 粗大モザイクの崖素しか与兄ず, 酸素を含を化合物の 炭化性改質困の難さを示唆している。ジヒドロアント 
ラセンとの共炭化 (1/1モル比) でも流れ構造の炭素を 与えるまでには至っていない。

同じ酸素を合む化合物である無水フタル酸触媒存 在下で等方性の炭素を与えるが，アントラセンと共炭 化しても同様に等方性のままである。

Marsh ら ${ }^{26)}$ は，加圧下に抢ける 異節環化合物の共 炭化反応を詳細に報告している。単独で加圧炭化を行 なうと，それぞれ等方性炭素を与える化合物でも，共 炭化することにより異方性が出現し，これを雨化合物 の共融効果によるネマティック液晶の形成によるもの であろうと指摘している。

Issacs ら ${ }^{27}$ は，無水フタル酸と異節環合物との加圧 共炭化で，無水フタル酸が熱分解によりベンザイン型 の高反応性中間体となり，異節環化合物に付加し，平 面性の高い多環化合物を生成してメソフェーズの形成 を助長する。この結果, 黒鉛化性が向上する。

これに対して, 塩化アルミニウムを触媒として共炭 化すると, フリーデルクラフト反応が起こり, 酸榇が 残存したまま付加し，これは非平面性より，高分子炭 素前駆体の浣積, 配列を妨害するため, 光学的異方性 組織の展開突䧎宮するのであろう。実際, 無水フタル 酸は単独の炭化では異方性炭素を生成するいかなる化 合物と共炭化しても，等方性の炭素空与兄る。高純度 等方性炭素は原子炉用しゃ蔽材等としての需要があ り，共炭化機構による舆方性展開とはまったく逆の方 向ではあるぶ，共炭化の応用としては與味学々研究で ある。

\section{ニードルコークスは主に電気慜鋼用電極として利用}

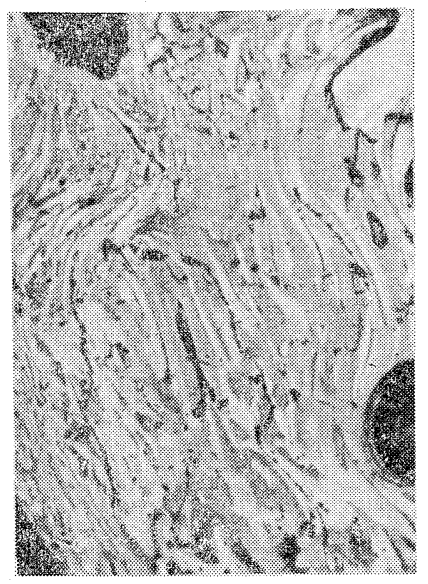

SRC - No.1

a) SRC No. 1
される付加価值の高い炭素材料のひとつで, 現在, 精 選された石油系ピッチから製造されている。他種のピ ッチからの製造を可能にし，原料種の拡大を計ること が試みられている。このためには，先にものべたとお り炭化条件の検討と原料ピッチの改質のふたとおりが 考光られる。共炭化法もその重要な一方法といえよう。 石油代替を目的として製造される液化石炭も現時点で は炭素材原料としての価值が高かろう。

筆者らは溶剂精製炭 (Solvent Refined Coal) ピッ チの炭化性を調べたところ, 使用した石炭種, 液化条 件によって, 生成するコークの光学組織が異なること 党見出し，その原因をピッチのベンゼン可溶分，不溶 分の共炭化性相性にあると判断して考察した ${ }^{28)}$ 。図 9 に 2 種の代表的 SRC ピッチより生成したコークスの 偏光顕徽鏡写真を示す。

SRC-No.1 ピッチは良好な流れ組織を与兄るが， SRC-No.2 ピッチはモザイク組織を与える。ところで 両ピッチのBS 成分からは流れ組織のコークスを生成 し, BI成 分はともに溶融せず, 等方性コークスを与 える。つまり, 非溶融の BI 成分は共存する BS 成分 に溶解して, ピッチ全体として液相炭化が実現し, 異 方性コークスを生成する結果となる。したがって，両 成分の混合状態の適否によって, 良好な流れ組織とな ったり，モザイク組織になったりするわけで，兩者の 組み合わせの良否,つまり炭化性相性によってピッチ の炭化性が定まってくると考学ることができる。実際 両SRC ピッチの BS 成分学入れか党て炭化すれば, SRC No. 1-BS/SRC No. 2-BI の組み合わ世加ら

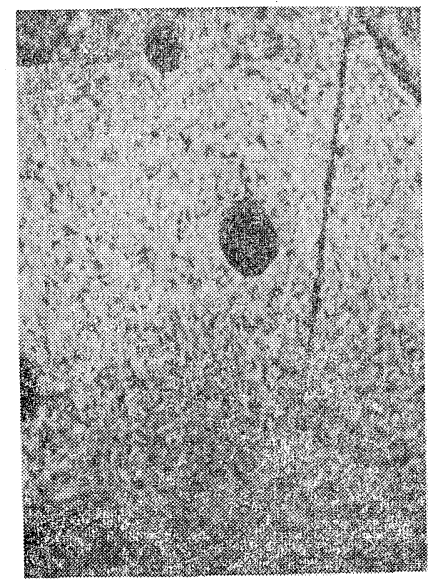

SRC-No. 2

b) SRC No. 2

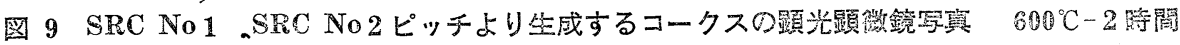



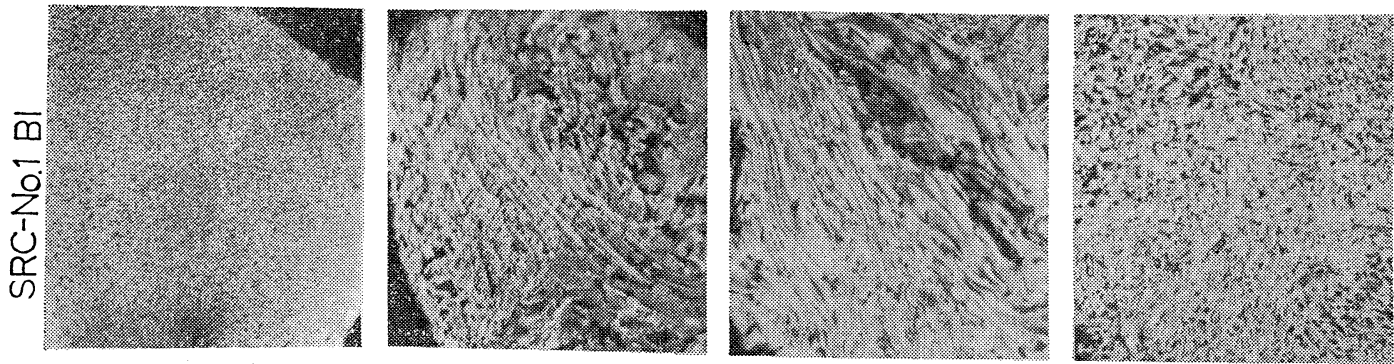

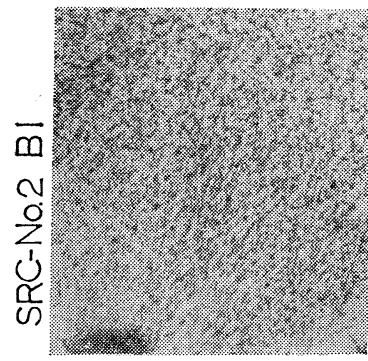

a)

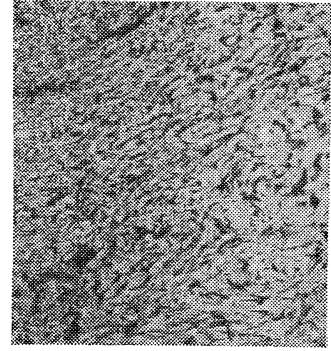

b)

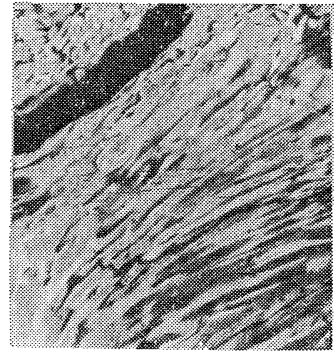

c)

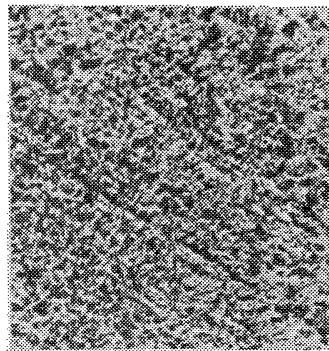

d) a) エチレンタール b) コールタールBS 上 SRC No $1 \mathrm{BI}$
c) SRC No $1 \mathrm{BS}$
d) $\mathrm{SRC}$ No $2 \mathrm{BS}$

下 SRC No 2 BI

圆 10 各整ピッチ BS 成分の SRC No1および SRC No2の BI 成分に対する岸化性相性 混合比 $\mathrm{BS} / \mathrm{BI}=6 / 4 \quad 600^{\circ} \mathrm{C}-2$ 時䦔

流れ組織が，SRC No. 2-BS/SRC No. 2-BI の組み 合わせからはモザイク組織が生成する。

このような相性は他のピッチ種との組み合わせでも 認められる。罒10に各種ピッチのBS成分と SR CNo.1 および SRC No.2 ピッチの BI 成分とおのおの $6 / 4$ の混

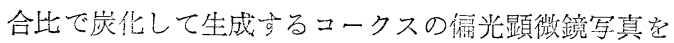
示した。ここで使用した BS 成分は, 単独で炭化すれ ば流れ組䋨を与えるのに，BI 成分との共炭化では， 相性の適否に忘じた璟方性組織が展開することが理解 できよう。

共宸化㤬相性の定量的記迹以混合比を加えて炭化性 を調べれば可能となる。四11に混合比をかえた時の岸 化性の変化を模式的に示した。図のような曲線の型か ら示される, 流れ組織形成に必要な最低の BS 成分量 をもって, 組み合わせた成分の相性の程度が表示でき る。良好な相性の組み合わせでは，10\%以下のわずか な BS 成分量でも流れ組織が展開する ${ }^{291}$ 。

相性の違いは, 本珼的にはピッチ BS 分の構造の差 に起因するふら， BS に適当な構造修飾を施すことに より，相性の改善が期待できる30)。 SRC ピッチとの 相性が極めて悪く, SRC-BI との共炭化により微小モ ザイクコークスを生成するエチレンタール (ET-BS)
を塩化アルミニウムを触媒として熱処理を行なうと， SRC-BI との相性は顕著に改善されて, 共炭化により ニードルコークスを生成する。塩化アルミニウムは先 にも述べたように，芳香族環の重縮合に伴って，ナフ テン環を創生するが，このナフテン環の水素が相性改 善に重要な役割を果たしていると考学られる。これは, 先に述べた 9,10 - ジヒドロアントラセンの場合と同様

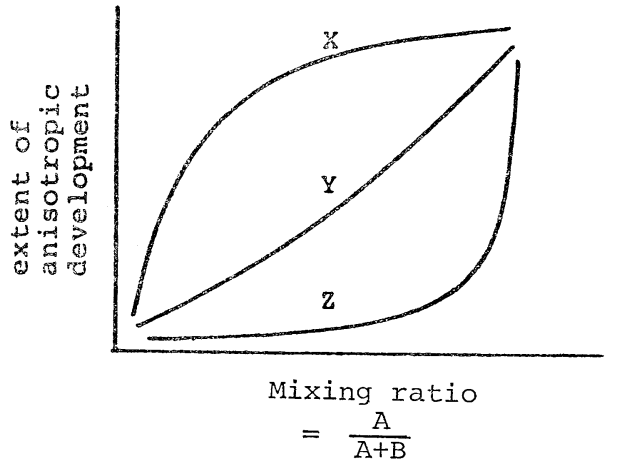

$\mathrm{X}$ : excellent partners $\mathrm{Y}:$ medium partners $Z$ : poor partners

図 11 共炭性の变化 
である。同じルイス酸触媒である熄化鉄，塩化銅を用 いて処理すると,縮合は進むが,ナフテン環が創生され ないため, 共炭化性相性は低い。しかし, 塩化銅での処 理後でも，水缶化すると SRC BI 成分との共炭化相 性は著しく改善され、ニードルコークスが生成する。

溶剂独出炭（Coal Extract）は溶融性のある石炭を アントラセン油を用いて抽出液化して得られるピッチ である。原炭は溶融性のある石炭に限定されるため, $\mathrm{SRC}$ 法よりも高価であるが, 抽出プロセスで水素を 使用しない利点がある。イギリス石炭庁 (National Coal Board)では，こうした抽出㟶からニードルコー クスを製造すること試みている。抽出炭の炭化性は $\mathrm{SRC}$ 法以上に原炭の炭化度に強く依存する。抽出収 率の低い準無煙炭からの抽出炭は流れ組織を与える が, 抽出收率の高い強粘炭, 弱粘炭からは扔の沶の粗 または微小モザイク組織のコークスが生成する31)。こ の炭化では，残留するアントラセン油が生成コークス の光学組織に影響し, モザイク単位の寸法の拡大に寄 与する ${ }^{22)}$ 一種の共孷化効果が認められる。このよう に, 抽出炭加ら良好なニードルコークスを製造するに は何らかの土夫が必要となる。

Marsh ら扮よび持田 ${ }^{33)}$ はこの問題を共炭化により 解決する方法を計った。NCB では主として強粘炭 (NCB 301) より抽出炭（D 112）を製造しているから， 同ピッチに石油系ピッチ (Ashland 社), SRC ピッチ (Gulf), 水㸃化抽出炭を添加して共炭化した結果, そ れぞれの共炭化性は相性に応じた混合比で，良好な流 れ組織が展開することを認め, 共炭化の有用性を報告 した。

さらに䈉者らは ${ }^{34)}$, カフジ減圧残油の SRC ピッテ との共岸化性相性の改善を調べたが, その結果, SRC No.1-BI との良好な相性は塩化アルミニウム処理に よる改䁈法により達成できるが，SRC No.2-BI に対 しては, 同処理では不十分で, さらに水素化が必要で あることがわかった。塩化アルミニウム処理に際し て, 硫化水素が多量に発生するため, この点でのピッ チの品位は向上するが，ナフテン水素の生成が阻害さ れるため, 共岸化性相性が十分に改善されず, 水素化 処理が必要であると理解している。

\section{4. 共炭化機構}

炭化反応に和いて光学的巽方性組織の展開する機構 について络すでにのべたが, 共炭化は上述の機構が作 動するように, 反応を制御したため, 炭化性が改善さ れたと考允られる。A成分 (添加剂)をB成分（主炭 化剂) に添加し, B成分の炭化性が改質される機構と
しては, 次の 4 つが考光られよう ${ }^{35)}$

(1) A成分から生成した液晶ラメラ中にB成分, ま たはその派生物が組み込まれる。ラメラ中に組み 込まれた分子は，たと立単独では液晶を形成する ことが困難であっても, 液晶の構成分子として積 層構造をとり，炭化反応が進む。

（2） A成分，またはその派生物が炭化過程に打いて 溶媒としての働き, 炭化系全体に対して低粘性の マトリックスを提供する。

(3) A成分が B成分と反応することにより孷化反応 が進行し, 炭化速度, 炭化中間体の構造を制御し て, 異方性の展開を助長する。

(4) $\mathrm{A}$ 成分が $\mathrm{B}$ 成分との反応を通して, 本来溶融 性, 溶解性の低い成分抢上び派生物に溶解性, 溶 融性を付与する。例总ば，A成分からB成分への 水素移動やアルキル基移動といったソルボリシ ス反応が起こる。

水素化されたルイス酸改質エチレンタールピッチの SRC No.1-BI に対する相性が改善された結果は(4)の 機構を示唆し, 無水フタル酸の添加効果に対する

Issacsら 27)の理解は(2)の機構である。またMarsh ら 26) の理解は(2)の変形といえよう。

チアンスレンとアントラセン, アクリジンとアント ラセンの共炭化反応 (1/1モル比) における低温溶解域 での BI の增加速度を単独の炭化と比較すると, 共炭 化の速度は幾分ゆるやかになっており, 溶融域もアク リジンの場合は特に広がっている25)。つまり，共炭化 により芳香族分子の積層と調和した分子の重縮合高分 子化が可能になっていると思われる。また，炭化中間 体中の BS 分の脂肪族水素と芳香族水素の比をとる と, 単独の炭化に比べて脂肪族水素がかなり増加し, 溶融域の搪大に対応しているとい圭よう ${ }^{25)}$ 。炭化中間 体の構造加らても，アントラセン（A成分）とアク リジン，またはチアンスレン（B成分）が反応し，炭 化速度, あるいは炭化中間体の構造を制御するという (3)の機構を示唆している。ナフタレンとピレンとの共 炭化も同様の機構によるものと思われる。デカサイク レンに添加したアセナフチレンがメソフェーズ出現温 度を低下させる ${ }^{36)}$ 。デカサイクレンはアセナフチレン 炭化の中間体と考光られているのにもかかわらず，反 応性が後者より低いことも考えて，アセナフチレンか ら誘導される反応性の高い中間体が, 炭化反応を先導 していると考觉られる。この共炭化は前述の(1)，また は(3)の機構といえよう。 


\section{5. 共炭化法の展開}

これまで, 共炭化法による生成コークスの光学的異 方性組織展開の制御について述べてきたが，炭化反応 機構からも理解できるように, 光学的暴方性組織展開 と黒鉛化性とは, その問題とする方法は大きく異なっ ているにかかわらず，機構上共通する面が多い。した がって, 共炭化法による黒鉛化性の制御については, 全く同様に报うことができる。筆者らはこのような観 点から成分ピッチの黑鉛化性を検討し, 報告してい $3^{377}$ 。

光学的異方性組織展開は炭化反応系の液相維持と要 約できることは先にのべた。反応系の液相維持は分解 軽質化, ピッチ化, 脱硫反応に打いても重要な因子で あるから, 共炭化法の概念でこれらの反応の条件改善 に応用できる。筆者らは酸触媒による脱硫反応に打け る共存溶媒の影響について検討し, 水素供与性化合物 の添加が脱硫反応を促進する例を見出している38)。コ バルトーモリブデン触媒を用いる水素化脱硫反応の場 合にも，水素供与添加の影響孞二，三報告されている が，現時点では結果は矛盾している399。

製鉄用コークス源である強粘結炭は世界的に欠之す る傾向に山る。この解決策として, 成型炭そう入法, 成型コークス法, 粘結剤添加法などが提案されている が，いずれにしても良好な粘結剂の開発が，必要で市 る ${ }^{40)}$ 。ところで, 製鉄用コークスの光学的異方性展開 は強度, とくに反応性, もしくは反応後強度と関連す る構造因子と考兄られている。したがって, 強粘結炭 を一般炭で代替する際に, 一般炭からも光学的異方性 組織が展開するような工夫が必要である。この際, 添 加粘結剂を石孷に対する共炭化添加剤と考光れば，こ れまで述べてきたことと同様の考察が可能となる。筆 者らは現在この問題にとり組んでいるので, 次の機会 に紹介したい42)。

\section{6. 縮語}

炭化反応における光学的異方性組織の展開を目的と する共炭化法について紹介した。序にも述べたとお り，現在ほど，重質岸素資源の高度有効利用法の開発 が強く期待されている時はなく, 科学者技術者が総意 を結集してその実現に努力する必要がある。この種の 技術開発には，今日の常識学こ克，発想を転換した新 機軸な研究に基づくものと，常識学集大成した大型実 用化技術の確立という二面がある。前者は，いわば “草の根”をかきわける根気のよい，かつ広範でち密 な基礎研究の成果から生まれてくるものである。諸賢 の一層のご努力とご支援を打願いこいたい。この小編
がこの分野で活躍される皆様の炭化反応設計のご理解 への一助になれば幸いである。本編に紹介した研究の 一部は文部省科学研究費初よび通商産業省サンシャイ ン計画の援助で可能になったことを記し，感謝にかえ たい。

1) J. L. White, Petroleum Derived Carbons 21 282 (1976)

2）倉見英一，石油学会誌，16，366（1972）

3) P. L. Walker, JR. Carbon, 10, 369 (1972)

4）藤巻洋人，小玉富美雄，太谷杉郎，炭素， 1975 (No. 80) P. 3

5) J. D. Brooks, \& G. H., Taylor, Chemistry \& Physics of Carbon, Vol. 4, 243 (1968)

6) I. Mochida, M. Ogawa, \& K. Takeshita, Bulletin of the Chemical Society of Japan, 49 (2) 514 (1976)

7) I. Mochida, K. Kudo, N. Fukuda, \& K. Takeshita, Carbon, 13, 135 (1975)

8) J. W. Patrick, M. J. Reynolds \& F. H. Show Carbon, 13, 509-514 (1975)

9) I. Mochida, K. Maeda, K. Takeshita, High Temperatures-High Pressures, 9, 123 (1977)

10) I. Mochida, E. Nakamura, K. Maeda \& K. Takeshita, Carbon, 13, 489 (1975)

I. Mochida, E. Nakamura, K. Maeda \& K. Takeshita, Corbon, 14, 123 (1976)

11) I. Mochida, T. Ando, K. Maeda, \& K. Takeshita, Carbon, 16, 453 (1978)

12) 持田勲, 安藤隆, 前田恵子, 藤津博, 竹下健次郎 炭素材料学会第 5 回年会要旨集 p. 8 (1978)

13) J. K. Brown, \& W. R. Ladner, Fuel 39, 87 (1960)

14) T. Edstrom \& J. C. Lewis, Carbon 2 85(1969)

15）大谷杉郎, 大島利道, 大谷朝男, 大田悦郎, 炭素 No. 77, 45 (1974)

16) I. Mochida, K. Maeda, K. Takeshita, Carbon, 16, 459 (1978)

17) J. Dubois, C. Agache, \& J. L. White, Metallography, 3, 337 (1970)

18）木村英雄, 真田雄三, 本田英昌, 然協誌, 49,752 (1970)

19) S. Otani, S. Watanabe, H. Ogino, K. Iijima \& T. Koitabashi, Bull. Chem, Soc. Japan, 45 , 3710 (1972) 
20）大谷朝男, 博士論文

21）松尾䆓二, 堀昭二, 大梘真一, 炭素材料学会 第 2 回年会要旨集 p. 108 (1975)

22) I. Mochida, K. Maeda \& K. Takeshita Fuel, 55,70 (1976)

23) I. Mochida, K. Otuka, K. Maeda \& K. Takeshita, Caróon, 15, 239 (1977)

24) H. Marsh, I. Macefield \& J. Smith, 13 th Biennial Carbon Conf., p. 304 (1977)

25) I. Mochida, T. Ando, K. Maeda, H. Fujitsu \& K. Takeshita, 14 th Biennial Carbon Conf., (1979)

26) H. Marsh, C. Hermon \& C. Cornford, Fuel, 53,168 (1974)

27) L. G. Issacs, Carbon, 6, 765 (1968)

28) I. Mochida, K. Amamoto, K. Maeda \& K. Takeshita, Fuel, 56, 49 (1976)

29) I. Mochida, K. Amamoto, K. Maeda \& K. Takeshita, Fuel, 57, 225 (1978)

30) 持田勲, 天本和馬, 前田恵子, 竹下健次郎, 石油 学会誌 20,1025 (1977)

31) H. Marsh, I. Mochida, E. Scott, Fuel 投稿中

32) M. Sheila, Jeffery, H. Marsh, I. Mochida \& E. Scott, 14 th Biennial Carbon Conf. (1979)

33) H. Marsh, I. Mochida, E. Scott, 14 th Biennial Carbon Conf. (1979)
34) 持田勲, 田原兔, 藤津博, 前田恵子, 竹下健次郎 炭素材料学会第 5 回年会要旨集 p. 10 (1978), 石 油学会投稿中,

35) I. Mochida, H. Marsh, K. Takeshita 14 th Biennial Carbon Conf, (1979)

36) 持田勲 H. Marsh, 竹下健次郎 炭素材料学会 第 5 回年会要旨集 p. 14 (1978)

37) 持田勲, 天本和馬, 前田惠子, 竹下健次郎, 石油 学会誌, 22, 114 (1979)

38) I. Mochida, K. Maeda, K. Takeshita, N.Kaji, Y. Suetsugu, T. Yoshida, Fuel Processing Technology, 1 (1977/1978) 103-105

39) G. Doyle, Division of petroleum chemistry. Inc. American Chemical Society 21, 165(1976)

40）井田四郎，燃協誌，56，221 (1977) 真田雄三，燃協誌，54，70 (1975)

41）井田四郎, 木庭敬一郎, 山下豊, 坂田康二, ニー クスサーキュラー 27, 261 (1978)

42) I, Mochida, K. Amamoto, K. Maeda, K. Takeshita \& H. Marsh, Proceedings of the Fif th London International Carbon \& Graphite $\mathrm{Co}_{-}$ nference, 237 (1978)

I. Mochida, H. Marsh \& A. Grint, Proceedings of the Fifth London Internationa 1 Carbon \& Graphite Conference 245 (1978)

\title{
Basic Ideas for the Development of Anisotropic Flow Texture in the Carbonization Process
}

\author{
Isao Mochida, Takashi Ando, and Kenjiro Takeshita \\ (Research Institute of Industrial Science, Kyushu University, Fukuoka, Japan)
}

SYNOPSIS:-Based on the fundamental understanding of the carbonization mechanism, some ideas for the development of anisotropic flow texture in the produced coke were reviewed. The co-carbonization process may be the most useful one which can develop the optical texture in any form from any carbonizing material, in principle, by means' of suitable additive. In the best process, no modification of external conditions for the carbonization is requested to obtain a coke of best quality such as a prime needle coke. The compatibility of the co-carbonizing substances is introduced to explain and describe ather quantitatively the effect of co-carbonization. The efficiency of an additive is discussed from the view of its chemical structure and reactivity. 